\title{
第4回 英国
}

\section{兼子利夫 1}

著者抄録 : 世界的に1990年代からインターネットとPCが急速に普及し始め, 産業活動はもちろんの こと一般社会にもその活用が広がりつつある。そのひとつのビジネス形態が, 電子商取引である。各 国の政府機関等では，これらの情報技術（Information Technology: IT）を積極的に政策に取り込み， 自国のIT政策として展開している。本稿では，最初に英国のIT政策の経緯について記述する。そし て, 包括的なIT政策であるUK onlineについて概観する。さらに, 内閣府に設置されたIT推進機関で あるOffice of e-Envoy, Office of e-Envoyに代わる新しい組織である電子政府局, UK Onlineに代わる 新しいオンライン・サービスであるDirect.govについて記述する。最後に, 英国のITを含む科学技術 政策を推進している貿易産業省の「5か年プログラム」について記述する。

キーワード : UK online, e-Envoy, 電子政府局, Direct.gov, 貿易産業省, 5か年プログラム

\section{IT Policies of the Major Countries and Economies No. 4 The United Kingdom}

\section{KANEKO Toshio ${ }^{1}$}

Author Abstract: The Internet and PCs have been spreading in the world since the 1990s. The usage of these technologies has been expanding not only in the business field but also in the ordinary society. One of those business styles is Electronic Commerce. Most of the governments of countries and economies are taking these information technologies into their policies and developing them as their own IT policy. This paper, first, takes a general view of the IT policy progress of the United Kingdom. And then it describes UK online which is a comprehensive IT policy, the Office of e-Envoy, the e-Government Unit, Direct.gov which is a new online service for UK online. And last it mentions the five year program by the Department of Trade and Industry.

Key words: UK online, e-Envoy, e-Government Unit, Direct.gov, Department of Trade and Industry, five year program

\section{1. 英国におけるIT政策の経緯}

本章では，英国政府の情報技術（Information Technology: IT）政策の最近の経緯について概観す る。

1996年2月, 英国政府による最初の包括的なIT政 策である「情報社会イニシアティブ (Information Society Initiative）」が発表された。ビジネス, 保健 医療，教育，行政等の分野をカバーするもので，5 か年計画（1996-2000年）として開始された。その 後,「情報社会イニシアティブ」は, 2000年9月に
新たに「UK Online」というIT政策に置き換えられ， $「 \mathrm{UK}$ Online」が, 英国政府における包括的なIT政策 と位置付けられた。

1998年12月,「競争の未来 : 知識集約型経済の構 築」が発表された。政府の課題を次のように設定 した。

(1)2002年までに英国を電子トレーディングに とって最適の環境にする。

(2)ITを活用することによって, 英国の中小企業 をG7の中でもトップのレベルに引き上げる。

1999年3月,「政府近代化白書」が発表された。本

1 (財) 日本情報処理開発協会＼cjkstart調査部（干105-0011東京都港区芝公園3-5-8 機械振興会館内）Tel. 03 (3432) 3467 E-mail: tkaneko@res.jipdec.jp

${ }^{1}$ Research Department, Japan Information Processing Development Corporation (JIPDEC) (Kikai Shinko Kaikan Bldg. 3-5-8 Shibakoen, Minato-ku Tokyo 105-0011) 
白書は，政府がIT戦略を確立する予定であること を明らかにした。この戦略のもとに, 市民や企業 に電子サービスを提供し,「情報時代に向けた中央 ／地方の協約」を設定した。さらに, データ標準, デジタル署名, スマートカード, デジタルTV, Web サイト, 政府のゲートウェイとポータル, 企業向 けのオンライン・サービス等, さまざまなテーマ について, 枠組みとなる政策とガイドラインを導 入した。また市民と政府の間の決済についても電 子化し, データの保護を図った。ターゲットは 2008 年に定められた。

1999年9月,内閣府の業務推進・刷新部門 (Performance and Innovation Unit in the Cabinet Office) は, 「ecommerce@its.best.uk」を発表した。この報告には， 上記の「競争の未来：知識集約型経済の構築」にお いて設定された，電子商取引に関する政府目標達成 のための戦略を明確にした。

2000年9月,「UK Online年次レポート 2000年」(第 1版）が, 発表された。このレポートはe-Ministerの パトリシア・ヒューイット（Patricia Hewitt）とeEnvoyのアレックス・アラン（Alex Allan）によって 監修され，政府や産業界のパートナーとの協力の もとに作成された。本レポートは英国をオンライ ン化するための戦略を詳細に定め, 以下の5つの ゴールを提起している。

\section{5つのゴール}

(1) 自信に満ちた人久 : 情報通信技術へのアクセ スに加えて, 情報通信技術を使ううえでの信 頼, スキル, モチベーション

(2) ビジネスの成功: 経済の各分野で情報通信技 術をビジネスに利用して成功している企業

(3) 見本としての政府: 公共セクターにおける最 先端のテクノロジーの活用

(4) 世界一級の供給センター : IT, 電子, 通信の 供給センター

（5）近代的な市場：消費者（企業や政府との関係 における個人）保護, 企業の競争とイノベー ションを促進する市場の枠組

2000年9月,「UK Onlineキャンペーン」が発表さ れた。3つのイニシアティブによって構成されてい る。

（1）国民をオンラインにつなぐ

(2) 企業をオンラインにつなぐ

(3) 政府をオンラインにつなぐ

この政策において，2005年までに政府のサービ スをすべてオンライン化すると目標を定めている。 2001年11月，「UK Online年次レポート２001年」
（第2版）が，発表された。市場の近代化，国民の 能力向上, 企業の活性化, 政府のオンライン化, 世 界的水準のサービス提供という5つの重要課題を取 り上げており，下記の 3 つ目標を表明した。

(1) 2002 年までに英国を電子商取引の世界で最も 整備された安全な環境にする。

（2）2005年まで希望者全員がインターネットにア クセスできることを保証する。

(3) 2005年までにすべての行政サービスが電子的 に利用できるようにする。

2002年11月,「UK Online年次レポート 2002年」 (第3版)が,発表され,下記の3つの目標を表明した。

(1) 英国を電子ビジネスにおける世界のリーダー として発展させる。

(2) 2005年までにすべての行政サービスが電子的 に利用できるようにし, 重要なサービスにお いては高いレベルでの使用を実現させる。

(3) 2005年まで希望者全員がインターネットにア クセスできることを保証する。

2003年12月,「UK Online年次レポート 2003年」 （第4版）を発表するとともに, 従来のOffice of eEnvoy（OeE）に代えて電子政府局（e-Government Unit）を設置する考えを明らかにした。また, 本し ポートの評価を受け, OeEは2004年3月, ukonline. gov.ukに代わる英国政府の新しいオンライン・サー ビスDirect.govを発表した。

表1に英国政府における主要情報技術政策の経緯 を示す。

\section{UK online}

本章では，英国における包括的なIT政策の一環 であるUK onlineについて概観する。

UK onlineは, 英国を世界における主要な情報経 済国にするための構想で, 政府, 産業界, 消費者 団体および国民に関する情報をオンラインで効率 よく活用できるようにするための政策である。

2000 年9月に英国政府がUK onlineを発表して以 降, 年次報告書は, 2002年11月に報告された「2002 年UK online年次報告書」で第3版を迎える。この年 次報告書は, 今日の世界経済におけるリーダーと しての英国の地位を確立するという包括的な目標 に基づいて, 政府, 企業および市民という主要分 野ごとに設定されたUK online 戦略の進渉(ちょく) 状況, ならびに今後の課題, ひいては将来のUK online 戦略について記載している。 
表1 英国政府 主要情報技術政策経緯

\begin{tabular}{|c|c|c|}
\hline 発表時期 & 政 策 & 概 要 \\
\hline 1996 年 2 月 & 情報社会イニシアティブ & $\begin{array}{l}\text { 英国政府による最初の包括的な取り組みであり, ビジネス, 保健医療, } \\
\text { 教育, 行政等の分野をカバー, } 5 \text { か年計画 (1996-2000 年) として開始, } \\
5,800 \text { 万ユーロの予算 }\end{array}$ \\
\hline 1998 年 12 月 & $\begin{array}{l}\text { 「競争の未来: 知識集約型 } \\
\text { 経済の構築白書」 }\end{array}$ & $\begin{array}{l}\text { ・2002 年までに英国を電子トレーディングにとって最適の環境にする } \\
\text { ・I を活用することによって, 英国の中小企業を G7 の中でもトップの } \\
\text { レベルに引き上げる }\end{array}$ \\
\hline 1999 年 3 月 & 「政府近代化白書」 & $\begin{array}{l}\text { 市民や企業に電子サービスを提供し, 「情報時代に向けた中央／地方の協 } \\
\text { 約」を設定, ターゲットは } 2008 \text { 年 }\end{array}$ \\
\hline 1999 年 9 月 & e-commerce@its.best.uk & $\begin{array}{l}\text { 内閣府の業務推進・刷新部門による。上記の「競争の未来」において設 } \\
\text { 定された, 電子商取引に関する政府目標達成のための詳細な戦略 }\end{array}$ \\
\hline 2000 年 9 月 & $\begin{array}{l}\text { UK Online 年次レポート } \\
2000 \text { 年 第 } 1 \text { 版 }\end{array}$ & 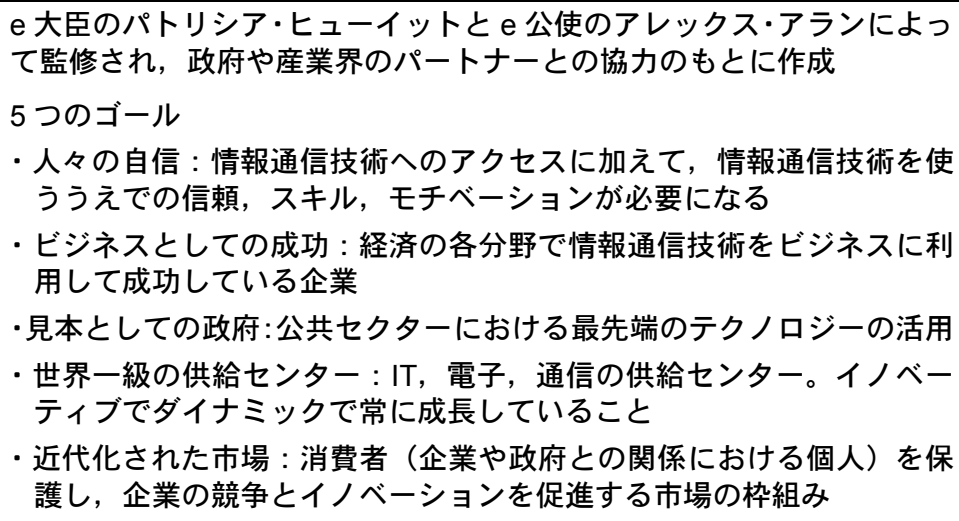 \\
\hline 2000 年 9 月 & UK Online キャンペーン & $\begin{array}{l}\text { 3 つのイニシアティブ } \\
\text { ・国民をオンラインにつなぐ : 家庭や職場から誰もがアクセスできるオ } \\
\text { ンライン・トレーニングコース「learndirect」を設置 } \\
\text { ・企業をオンラインにつなぐ : 面談やオンライン, あるいは電話による } \\
\text { 専門家のアドバイスを提供することにより, 企業が新しいテクノロ } \\
\text { ジーを活用するのを助ける。 } 2000 \text { 年に } 1,650 \text { 万ユーロ, その後 } 2 \text { 年間 } \\
\text { に } 2,490 \text { 万ユーロを支出（旧名称 : Information Society Initiative） } \\
\text { ・政府をオンラインにつなぐ : } 2005 \text { 年までに政府のサービスをすべてオ } \\
\text { ンライン化。今後 } 3 \text { 年間に } 17 \text { 億ユーロの予算 }\end{array}$ \\
\hline 2001 年 11 月 & $\begin{array}{l}\text { UK Online 年次レポート } \\
2001 \text { 年 第 } 2 \text { 版 }\end{array}$ & $\begin{array}{l}\text { 市場の近代化, 国民の能力向上, 企業の活性化, 政府のオンライン化, } \\
\text { 世界的水準のサービス提供という } 5 \text { つの重要課題 }\end{array}$ \\
\hline 2002 年 11 月 & $\begin{array}{l}\text { UK Online 年次レポート } \\
2002 \text { 年 第 } 3 \text { 版 }\end{array}$ & $\begin{array}{l}\text { 3つの目標を表明。(1) 電子ビジネス, (2) オンライン行政サービス, (3) } \\
\text { 国民のインターネット・アクセス に関する目標 }\end{array}$ \\
\hline 2003 年 12 月 & $\begin{array}{l}\text { UK Online 年次レポート } \\
2003 \text { 年 第 } 4 \text { 版 }\end{array}$ & $\begin{array}{l}\text { ICT を活用してサービス提供を変革し, 公共部門全体の運営効率を改善 } \\
\text { することを将来の課題として特定し, こうした変革を支える } 5 \text { つ原則 } \\
\text { を提示 }\end{array}$ \\
\hline 2004 年 3 月 & Direct.gov & $\begin{array}{l}\text { ukonline.gov.uk に代わる英国政府の新しいオンラインサービス } \\
\text { Direct.gov を発表 }\end{array}$ \\
\hline
\end{tabular}

出典 : 英国政府等発表資料から作成

2002年UK online年次報告書 :

・e-Government政策による公共サービス提供の 変容および政府自体の業務の効率化という別々 の課題を, 政府全体による公共サービスの包 括的改革として統合した。

・英国を世界の電子商取引に最適な国として位 置付けるうえでの, 重要なデータを提示して いる。つまり, 昨年度実施した調査により, 政
府,企業および市民のIT能力に影響を与える重 要な要因が明らかにされ, 英国は, 世界におけ る電子商取引の最適環境を備えた国として米 国に次いで第2位を占めていることが示された。 政府, 企業および市民の分野では, おのおの以 下の目標を定めており, それに沿った戦略を策定 している。

政府の目標 : 全行政サービスの電子的利用を 2005 
年までに実現。特に重要なサービス の利用を推進

企業の目標 :e-business の分野における世界的リー ダーとしての英国の地位確立

市民の目標 : インターネット・アクセスを希望す る市民全員へのアクセス提供を 2005 年までに実現

\section{1. 政府}

戦略

(1) 政府の変革

これは，以下により実現する：

・行政サービスのオンライン化に対する政府の 役割についてのビジョンの見直し

・行政サービスの利用方法の変更および政府自 体の業務の効率化

・2005年以降のe-Governmentプログラムの方針に 関する長期的なビジョンの作成

(2) ユーザ中心の政府

これは，以下により実現する：

・国レベルおよび地方レベルにおける重要な行 政サービスの充実化

・ 中核となる e-Governmentプログラムを確実に 提供するとともにリスクを最小化するため,中 央政府によるリーダーシップの発揮

・変革を妨げる障害の克服

・市民の求める方法による行政サービスの提供

・民主主義的プロセスの強化

(3) 政府自体の業務の効率化

これは, 以下により実現する：

・重要な行政サービスの利用を促進

・仲介業者を経由した，ユーザの選択する方法 での行政サービス利用の促進

・サービス提供基準の共通化

·政府間における共通インフラの提供

\section{2. 企業}

UK onlineにおける企業向けの戦略は, 以下のと おりである。

(1) 企業の変革

これは,UK online for business事業をとおして,企 業のe-commerceからe-businessへの移行を支援する ことで実現する(これまで, 英国政府はe-commerce という表現を使っていた。しかしこれは，主にオ ンライン上での商取引を意味するもので,ICTを顧 客管理, 調達, サプライ・チェーン等のより広範 な分野において利用するという観点から,e-business
という表現に変更された)。

(2) ブロードバンドの開発

これは, 産業界と共同で英国のブロードバンド 市場の規模拡大および競争力強化を継続すること で実現する。

(3) 枠組み構築への支援

これは, e-economyのニーズを満たすため, 英国 の法規則上および財政上の枠組みを近代化するこ とで実現する。

(4) スキルの強化による生産性の向上

これは, 英国がICTスキル提供の第一人者とし て, 生産性向上のための戦略を実施することで実 現する。

\section{3. 市民}

UK onlineにおける市民向けの戦略は, 以下のと おりである。

(1) インターネットに関する啓蒙（もう）

これは, 市民がアクセスできる行政サービスお よびその場所について，市民に情報提供すること で実現する。

(2) 家庭, 職場, 移動中およびコミュニティ内で のインターネット・アクセス環境の充実

これは, PC, デジタルTVおよび公共のインター ネット・アクセス・ポイントを含めたさまざまな アクセス・チャンネルの提供を支援することで実 現する。

(3) ICTスキルの向上

これは,インターネットを利用するうえで必要 なスキルおよび自信を得る機会を市民に提供する ことで実現する。

(4) インターネットに対する信頼性の醸成

これは, インターネットを安全に利用する最善 方法を市民に広め, 消費者の信頼性を向上させる 整合性のとれた規則枠組みを構築することで実現 する。

\subsection{UK online 戦略の進渉状況}

UK online annual report 2002発表当時のUK online 戦略の進捗状況は, 以下のとおりである。

·英国の従業員の $91 \%$ \%インターネットに接続 された企業に雇用されている

・企業の $73 \%$ 業務をオンライン化

・企業の $62 \%$ \% Webサイトを設立

・企業の $51 \%$ \%オンライン上で購入を経験

・企業の $30 \%$ がオンライン上で販売を経験

·電子商取引の取引高は184億ポンド(約3.7兆円, 
2003年7月 2 日為替レート: 1 ポンド $=$ 約201.8円。 特記がなければ,以下の円換算額は左記のレー 卜に基づく）に上る

・ 一般家庭の $45 \%$ \%゙インターネットに接続

・昨年38\%だった習慣的にインターネットを利 用する成人の割合が $47 \%$ に増加

・2000年9月に2,000か所だったUK onlineセンター を，6,000か所に増設

・ インターネットとPCとの普及率の格差が 4 年前 の $23 \%$ から約 $11 \%$ に縮小

\section{3. e-Envoy}

本章では, e-Envoy（Envoyとは，外交使節とか 特命全権公使というような意味, したがって, eEnvoyは「電子公使」というような意味）について 概観する。

Office of e-Envoy（OeE）は，1999年9月に内閣府 内のPrime Minister's Delivery and Reform team の一 部として設立された組織である。OeEは，2005年 までに全市民のインターネット・アクセスを実現 するという英国政府の目標に基づき，オンライン 化した政府サービスを統合することによって, 市 民，企業など英国全体に提供する公共サービスを 改善し，長期的に費用を削減することをその主な 任務としている。

OeEの主要な業務分野は以下のとおりである。

- e-Communications

- e-Delivery

- e-Economy

- e-Government strategy

- e-Democracy

- Getting government online

上記の業務分野の主な内容は以下のとおりであ る。

\section{1. e-Communications}

e-Communicationsグループは,UK onlineの通信イ ンフラ整備を主眼として, 以下の5つの目標を設定 している。

・多数のチャンネルにより, UK onlineの双方向 サービスの開発および提供

- Knowledge Network（KN）インフラを提供する ことにより，政府内の情報共有化を拡大

・OeE内外および政府内においてOeEのコミュニ ケーション推進力を強化

・UK onlineプログラム（特に市場開発, ブラン
ド化およびキャンペーン）の指揮

·全政府のWebサイトの品質を向上するための共 同事業の調整，最善慣行および技術革新の推 進, e-communicatorsによる専門組織の設置

\section{2. e-Economy}

e-Economyは, 主にe-EconomyグループとeStrategyグループが担当する。e-Economyグループ は, e-Minister (Patricia Hewitt) およびe-Envoy (Andrew Pinder) に対して広範な分野にわたる Economyの責任事項に関する戦略的支援を行う。ま た，首相に対して月次報告および年次報告を提出 し,アクション・プランの更新, e-championsネッ トワークを管理する。

一方, e-Strategy グループは, 公共機関, 民間機 関および任意団体，ならびに国際機関と共同で, 英国政府による電子ビジネス環境の最善化を進め る。e-Strategy では, インターネット・アクセス, 市場の近代化および市場分析の3つの分野に注目し ている。この3分野における業務は以下のとおりで ある。

(1)インターネット・アクセス

これは, Marketing Development teamが管轄する。 同チームは, 他の省庁およびパートナーの協力に より，2005年までの全市民へインターネット・ア クセスの実現に向けた政策を策定し, プロジェク トを実施する。

(2)市場の近代化

これは, Marketing Analysis teamが管轄する。同 チームは, 政府の政策決定が信頼できる正確なeCommerce調查および分析に基づいて確実に行われ るよう支援する。

(3)市場分析

これは,Marketing Framework teamが管轄する。同 チームは, 適切な規制環境を整え消費者の信頼性 を向上させることに焦点を当てた Marketing Framework Policyを策定する。これにより, eCommerceを活用した活気と競争力のあるビジネス 界を構築する指導的役割を果たす。また, 同チー ムは, 首相に対して月次報告および年次報告を提 出し,アクション・プランの更新, e-championsネッ トワークを管理する。

(4)その他

上記の業務のほか, Ministerial Business局は, 全 般的な職務に対する連絡業務およびOeEのヘルプ デスク管理を行う。Private Officeは, e-Envoyに対 して行政上および戦略上の支援を行う。 


\section{3. e-Government strategy}

e-Government Strategyチームは, e-Government プ ログラムの中心となる政策および戦略的方針の策 定を任務とする。また同チームは，他の省庁と協 力してe-Government プログラムおよび公共サービ スの長期的包括的ビジョンを作成するとともに， その実現方法を検討する。これまでにも, OeEと 大蔵省との関係を改善し, また内閣の電子サービ ス提供小委員会 (sub-committee on Electronic Service Delivery）による作業プログラムの作成および共同 の概要説明において,OeEの指導的役割を果たした。

また, Security and Authentication Unitは, egovernmentサービスの信頼性を保証するため, 必 要な認証政策を策定するとともにセキュリティ上 の枠組みを構築する。

\section{4. e-Democracy}

これは, 電子投票による市民の投票機会の拡大, インターネットを通じた政府情報の収集および意 見交換, ならびに政府および英国議会による市民 の意見, 知識, 経験に関する情報入手のための新 しい場を提供する。e-Democracyの政策案には, 以 下の3つの目標が示されている。

・市民による民主主義的プロセスへの参加を拡 大：市民による公共情報の八手, 行政手続き, 政治問題に関する議論, 政府事業の調査, 投票 などの簡便化

・民主主義的コミュニケーションの新しいチャ ンネル導入による市民参加の拡大

・市民と国会議員との関係強化による市民参加 の高レベル化

\subsection{Getting government online}

政府によるe-Governmentを提供するための現在 の主なプロジェクトは, 以下のとおりである。

• e-Business Strategies

全省庁はe-business戦略の策定が義務付けられ ている。e-Business Strategiesには, 各省庁の詳 細なe-Business 戦略の実施方法が明らかにされ ている

· ESD 報告書の作成 OeEは,2005年の政府サービスのオンライン化実 現に向けた事業の進渉状況を示すESD (Electronic Service Delivery）報告書を年に2回作成する。 地方政府のオンライン化 地方政府も中央政府と同様にオンライン化を
推し進める。

- Government Gateway

政府のゲートウェイに登録することで，イン ターネットによる英国政府のサービスを利用 可能とする。

・ ukonlinegov.uk 市民向けポータル

現在オンライン化されている政府の情報およ びサービスすべてを利用するための主要な窓 口となるWebサイトを提供する。

- Knowledge Network (KN)

KNは，省庁を電子的に接続し，政府関連情報 へのアクセスをより拡大する。また, 省庁内外 の協力関係を強化し，オンライン化された情 報および知識を共有するためのサイトを設立 する。

・情報化時代に適した法律の近代化 成文法では, 書面における署名, 文書作成など が規定されており, e-commerce およびegovernmentの障害となっている。このため, 2000 年のElectronic Communications Actによりこれら の障害を排除するとともに，より効率的かつ 安価な方法への移行を進めている。

\section{4. 電子政府局}

本章では, Office of e-Envoy（OeE）に代わる新 しい組織である電子政府局 (eGU: e-Government Unit）1)について概観する。

電子政府局 (e-Government Unit) は, 英国の内閣 府に設置されている最大の組織であり，2004年か らOeEの業務を発展的に引き継いだ組織である。よ り効率の高い公共サービスの提供を目指すもので, 以下の政策を実施する。

(1)IT政策の立案

(2)政府全体のIT活用の開発

(3)政府全体のIT活用の普及

(4)国民中心のオンライン・サービスの提供

OeEの業務と比べて新しい主な業務は, 以下の とおりである。

(1)市民中心の公共サービス

(2)政府における情報通信機器の再利用の最大化

(3)公共分野における認証の推進

(4)ITサプライヤーとのパートナーシップ

(5)共通インフラの開発

(6)知識ネットワーク・プロダクツ 


\section{Direct.gov}

本章では,UK Onlineに代わる新しいオンライン・

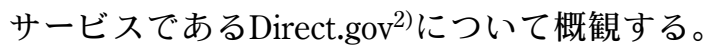

「2003年UK Online年次レポート」の評価を受け て, Office of e-Envoy (OeE) は, 2004 年3月, ukonline.gov.ukに代わる英国政府の新しいオンライ ン・サービスDirect.govを発表した。このサービス では, 多くの政府省庁の情報が1か所に集約されて いるため, 利用者が各省庁のサイトを検索する必 要がない。また, 省庁別ではなく, 学習, 健康, 地 域情報，旅行などのトピック別に整理された政府 情報を提供し，ユーザが自分に関係した情報を見 つけやすくしている。コンテンツは, 自動車の運 転者, 児童保護者, 障害者, 介護者, 国外居住者, 50歳以上の高齢者など, 明確に特定されたグルー プを対象としている。例えば障害児を抱える保護 者が地域の普通校に子供を通学させる場合, これ までなら, 教育技術省や労働年金省のサイトを個 別に訪問しなければならなかったが，Dicret.govな ら1か所で, 受けられる支援の種類やレベルまで調 べることができるようになる。

2004 年 3 月, 100 人のインターネットユーザに Direct.gov とukonline.gov.ukの両方を使用して一連 のタスクを遂行後, 評価してもらう実験を行った ところ, 8割のユーザがDicrect.govがUK Onlineより も優れていると回答した。さらにOeEは2004年4月 28日, Direct.govがSky, Telewest, NTLを通じてデ ジタルテレビ（DTV）ユーザにもサービスを提供 すると発表した。これにより，1,000万世帯近くが DTV経由でサービスを利用できるようになる。2004 年7月現在, ukonline.gov.ukのコンテンツはすべて direct.govに移行されている。

\section{6. 貿易産業省 5か年プログラム}

本章では, 英国のITを含む科学技術政策を推進 している貿易産業省の「5か年プログラム」につい て概観する。

貿易産業省(DTI: Department of Trade and Industry $)^{3)}$ は，2004年11月，「5か年プログラム」を 発表した。同省は, 英国における科学技術の振興, 科学技術の産業界への活用等を担っている。IT分 野についてもその政策のひとつとして掲げている。

\section{1. 背景}

この半世紀において英国が，G7に属する他のど
の国よりも急速で, 長く続く成長を経験したのは 今回が初めてのことである。結果として英国は, フランスを追い抜いて世界第4位の経済国となった。 ·英国は現在 400 万を超す企業を有し,これは 7 年 前より30万社も多い。新規ビジネスが1日に 1,000 社以上の割合で起こっている。倒産率も, 1993 年以後のどの時期よりも低い。

- 欧州の上位 600 社のうち3分の 1 近くが英国企業 であり，これは他のどの国よりも多い。

·英国は，欧州でも国内投資で第1位を保ってお り，また外国への投資も米国以外の国では最 も多くなっている。

·製造業においては, 英国の自動車産業は, かつ てない生産量を誇り, 欧州でも最も生産性の 高い自動車工場のいくつかが英国内にある。

·英国は医薬品産業の分野で世界第2位であり, 生物科学産業でも同じく世界第2位である。 ·英国のクリエイティブ産業—デザイン, 広告, 音楽, 映画やテレビ,ファッション,コンピュー タゲーム, 出版 一が英国全体の富に占める割 合も世界のどの国よりも大きい。EUにおいて, 商標や意匠登録が最も多いのは英国の企業で ある。

·英国の科学者は, 世界で最も活躍している。英 国の人口は世界の $1 \%$ あるるが, 科学者は世界 の科学者の5\%を誇り, 引用論文は世界で $12 \%$ に上る。

・ロンドンシティーは, 世界最大の金融中心地 である。

・世界の上位50の大学のうち,8つが英国にある。

\section{2. 直面する課題}

情報や通信技術の急激な躍進により, 英国のサー ビス部門は国際競争にさらされた。将来的には, コールセンターの職員だけでなく, 医療や科学分 野の研究者, 金融アナリスト, 大学の講師に至る 誰もが, 何千マイルも離れた勤務者と競いあうこ とになるだろう。

また, エネルギーの分野では, 北海（the North Sea）の化石燃料埋蔵量が減り, やがてガスの輸入 は輸出を上回り, 2010年ごろには, 石油の正味輸 八国となるだろう。

\section{3. 新しい産業政策}

5か年プログラムの期間中, 我々は引き続いて科 学ベースへの投資を行い，またナノテクノロジー や複合材料, バイオサイエンスなど, 未来のテク 
ノロジーのプログラムに4億ポンド近くの投資を行 うとともに，確実にビジネスを「やり抜き」，また 商業的利用に常に焦点を置いて, 新しいアイデア を新製品や雇用に転換していく。政府をより賢い 消費者にし,民間部門の改革を促進して,年間 1,250 億ポンドの公共調達プログラムで, さらに大きな 価值を得られるものとするよう支援する。

新しいDTIは, さらに能率的で, 柔軟, 機敏で, 賢いものとなるだろう。新しいDTI本省は, 2008年 までに4,000名以下の職員を雇用する予定である。 全体予算56億ポンドの内, 33億ポンドは科学や改 革に投資される。

\section{7. おわりに}

本稿では, 最近の英国のIT政策について概観し た。英国の包括的なIT政策は，1996年2月，「情報 社会イニシアティブ(Information Society Initiative)」 から始まると言える。本イニシアティブは, ビジ ネス, 保健医療, 教育, 行政等の分野をカバーす るもので,5か年計画（1996-2000年）として開始さ れた。その後,「情報社会イニシアティブ」は, 2000 年9月に新たに「UK Online」というIT政策に置き換 えられ,「UK Online」が, 英国政府における包括的
なIT政策と位置付けられた。「UK Online」は，英国 を世界における主要な情報経済国にするための構 想で，政府，産業界，消費者団体および国民に関 する情報をオンラインで効率よく活用できるよう にするための政策である。

その後, 2004年3月,「UK Online」に代わる英国 政府の新しいオンライン・サービス「Direct.gov」 を発表し, 現在に至っている。Direct.govは, UK Onlineと比較してより充実した効率のよい国民中 心のオンライン・サービスの提供を目指している。 英国政府のIT政策の推進の一翼を担っている貿 易産業省は，2004年11月，「5か年プログラム」を 発表した。同プログラムでは,引き続いて科学べー スへの投資を行い，またナノテクノロジーや複合 材料, バイオサイエンス等, 未来のテクノロジー のプログラムを推進していくとしている。

英国政府は，同国をIT分野で世界をリードする ために，産業界はもちろんのこと国民へのITの普 及を念頭に包括的なIT政策である「UK Online」を 開始し, それを引き継いだ「Direct.gov」を推進し ている。日本においてもITの利活用がひとつの課 題となっているが, 英国のIT政策の現状は今後の 展開も含めて参考になるものと思われる。

\section{参考文献}

1) e-Government Unit, Cabinet Office. "e-Government Unit”. (online), available from <http:// www.cabinetoffice.gov.uk/e-government/>, (accessed 2005- 06-16).

2) Direct.gov. "Direct.gov". (online), available from <http://www.direct.gov.uk/Homepage/fs/en >, (accessed 2005-06-16).

3) Department of Trade and Industry. "Five year programme". (online), available from <http:// www.dti.gov.uk/about/fiveyearprogramme.pdf? pubpdfdload $=04 \% 2 \mathrm{~F} 1871>$, (accessed 2005-06-16). 